Tracing the Jerusalem Code 3 



\section{Tracing the Jerusalem Code}

Volume 3: The Promised Land

Christian Cultures in Modern Scandinavia (ca. 1750-ca. 1920)

Edited by

Ragnhild J. Zorgati and Anna Bohlin

Illustrations edited by Therese Sjøvoll

\section{DE GRUYTER}


The research presented in this publication was funded by the Research Council of Norway (RCN), project no. $240448 /$ F10

ISBN 978-3-11-063488-4

e-ISBN (PDF) 978-3-11-063947-6

e-ISBN (EPUB) 978-3-11-063656-7

DOI https://doi.org/10.1515/9783110639476

\section{(cc) BY-NC-ND}

This work is licensed under the Creative Commons Attribution-NonCommercial-NoDerivatives 4.0 International License. For details go to: https://creativecommons.org/licenses/by-nc-nd/4.0/.

\section{Library of Congress Control Number: 2020952378}

\section{Bibliographic information published by the Deutsche Nationalbibliothek}

The Deutsche Nationalbibliothek lists this publication in the Deutsche Nationalbibliografie; detailed bibliographic data are available on the Internet at http://dnb.dnb.de.

(C) 2021 Ragnhild Johnsrud Zorgati, Anna Bohlin (eds.), published by Walter de Gruyter GmbH, Berlin/Boston.

The book is published open access at www.degruyter.com.

Cover image and frontispiece: Einar Nerman, cover design for Selma Lagerlöf's novel Jerusalem, 18th edition, Stockholm: Bonniers, 1930. Photo credit: National Library of Sweden

(Kungliga Biblioteket), Stockholm.

Typesetting: Integra Software Services Pvt. Ltd.

Printing and binding: $\mathrm{CPI}$ books $\mathrm{GmbH}$, Leck

www.degruyter.com 
In memory of Erling Sverdrup Sandmo (1963-2020) 
